International Water Resources Association

Water International, Volume 32, Number 1, Pg. 1-15, March 2007

(C) 2007 International Water Resources Association

\title{
The United Nations Watercourses Convention Ten Years Later: Why Has its Entry into Force Proven Difficult?
}

\author{
Salman M.A. Salman, Member IWRA, Lead Counsel, Legal Vice Presidency \\ The World Bank, Washington DC, USA
}

\begin{abstract}
After about 27 years of extensive preparatory work and formal and informal deliberations, the United Nations General Assembly adopted on May 21, 1997, by a large majority, the Convention on the Law of the Non-Navigational Uses of International Watercourses. The adoption of the Convention was hailed as a major breakthrough and as an historical moment in the evolution of international water law. However, ten years after its adoption, the Convention has not yet entered into force. This article reviews the history, basic features and status of the Convention, analyzes the reasons for the reluctance of states to become parties to it, and examines its role and prospects.
\end{abstract}

Key words: Dispute settlement, equitable and reasonable utilization, International Law Commission, regional economic integration organization, Watercourses Convention.

\section{Introduction}

The United Nations (UN) General Assembly adopted on May 21, 1997 the Convention on the Law of the Non-Navigational Uses of International Watercourses (UN Watercourses Convention, or Convention). That approval followed about twenty three years of extensive preparatory work by the International Law Commission (ILC), and lengthy deliberations by the Sixth (Legal) Committee of the General Assembly, as well as the General Assembly itself, that lasted for about three years. Furthermore, the work of the ILC drew from rich legal literature in the field. A number of declarations and resolutions on international watercourses, accompanied by detailed reports, have been adopted by two scholarly non-governmental organizations - the Institute of International Law (IIL), and the International Law Association (ILA).

The first such declaration was issued by the IIL in 1911, under the title "International Regulations Regarding the Use of International Watercourses for Purposes Other than Navigation," also known as the Madrid Declaration. This was followed by the
IIL "Resolution on the Utilization of Non-Maritime International Waters (Except for Navigation)" (the Salzburg Resolution) in 1961, and the resolution on "The Pollution of Rivers and Lakes and International Law" (the Athens Resolution) in 1979. On the other hand, the ILA started working on international watercourses in 1956 when it issued "A Statement of Principles upon which to base Rules of Law Concerning the Uses of International Rivers," also known as the Dubrovnik Statement. The Statement was followed in 1958 by the New York Resolution that dealt with the principle of reasonable and equitable sharing of the waters of a drainage basin. This principle was further discussed and elaborated by the ILA at the Tokyo meeting in 1964 . The work of the ILA culminated in the "Helsinki Rules on the Uses of the Waters of International Rivers" that were issued in 1966 (ILA, 1966). The Helsinki Rules were the first comprehensive set of rules dealing with international watercourses, and have been widely accepted as representing customary international water law (Bourne, 1996). It should, however, be noted that those declarations and resolutions have no binding effect per se. This is because they are neither signed nor 
ratified by states. Their authoritative guidance stems from the expertise and respectability of the members of both organizations.

In addition to the work of the IIL and ILA, mention must also be made of two conventions adopted under the auspices of the League of Nations. The first is the "Convention and Statute on the Regime of Navigable Waterways of International Concern," also known as the Barcelona Convention, adopted in 1921. This Convention deals mainly with issues related to navigation. The second convention is the "Convention Relative to the Development of Hydraulic Power Affecting More than One State," also known as the Geneva Convention, adopted in 1923. This Convention, as its title indicates, is quite limited in scope. Although both Conventions are still in force, they have little, if any, legal or practical relevance and usefulness (Berber, 1959).

In parallel to the above, there have been a large number of bilateral and multilateral treaties, as well as judicial and arbitral decisions, on international watercourses. As such, the ILC had considerable literature on international watercourses to start from, and indeed, it has acknowledged that, as will be discussed later.

Discussion of this extensive body of work is beyond the scope of this article. Instead, this article concentrates on the UN Watercourses Convention. It starts with discussion of the early work of the UN on international watercourses and the preparatory work of the ILC that resulted in the draft Convention. The article also reviews the provisions of the Convention, analyzes the reasons for the reluctance of the states to become parties to it, and examines the influential guidance it has provided, as well as its prospects.

\section{The United Nations Early Involvement with International Watercourses}

The UN started paying attention to the issue of international rivers in the late 1950 s. In 1959 , the UN General Assembly adopted Resolution 1401 (XIV), which called for initiation of "preliminary studies on the legal problems relating to the utilization and use of international rivers with a view to determining whether the subject is appropriate for codification."
The Resolution requested the Secretary General of the UN to prepare and circulate to the member states a report containing: (i) information provided by member states regarding their laws and legislation in force on the matter; (ii) a summary of existing bilateral and multilateral treaties; (iii) a summary of decisions of tribunals, including arbitral awards; and (iv) a survey of studies made by non-governmental organizations concerned with international law.

Consequently, a report, entitled "Legal Problems Relating to the Utilization and Use of International Rivers," was completed and presented to the General Assembly in April 1963 (United Nations, 1963). Volume I of the report was divided into two parts. The first part dealt with information provided by member states regarding their legislation on international waters, and the second part dealt with general conventions, as well as bilateral and multilateral treaties in Africa, America, Europe and Asia dealing with international waters. Volume II of the report included two parts which dealt with international judicial decisions, as well as studies carried out by national and international non-governmental organizations. Such studies included the early work carried out by the ILA, and the IIL. The report predated the Helsinki Rules on International Rivers issued by the ILA in 1966.

The report was widely circulated, but it took seven more years before the General Assembly would return to the issue of international watercourses. On December 8, 1970, the General Assembly adopted Resolution 2669 (XXV) entitled "Progressive Development and Codification of the Rules of International Law Relating to International Watercourses." The Resolution referred to the earlier Resolution 1401 of 1959 , and to the report that was produced as a result thereof, and underscored the facts that: (i) water, owing to the growth of population and to the increasing and multiplying needs and demands of mankind, is of growing concern to humanity; (ii) the available freshwater resources of the world are limited; and (iii) the preservation and protection of those resources are of great concern to all nations. The Resolution noted the legal problems relating to the use of international watercourses, and the fact that such use is still based on rules of customary law. The Resolution asked the International Law Commission (ILC) to "take up the study of the law of the non- 
S. M. A. Salman

navigational uses of international watercourses with a view to its progressive development and codification." It also requested the Secretary General of the UN to continue the study initiated under Resolution 1401 in order to prepare a supplementary report on the legal problems relating to utilization and use of international watercourses. It is worth noting that Resolution 2669 used the term "international watercourses" as opposed to the term "international rivers" used in Resolution 1401. The term "international watercourses" is more inclusive than "international rivers" because it includes lakes and groundwater, in addition to rivers. This indicates a clear progress in the global understanding of international waters issues.

About sevenyears after the issuance of Resolution 2669, the Secretary General of the UN completed and submitted in March 1977 a report entitled "Register of International River Basins." The report was discussed in May of that year by the Committee on Natural Resources of the UN Economic and Social Council. The Register indicated that the number of international rivers was 214 . It showed the riparian countries and the basin area of each international basin. It also indicated the share of each riparian country, as well as the total area of the country falling within the international basin. Indeed, the Register was quite comprehensive and its information fairly detailed (United Nations, 1977a).

It should be added that the Register was issued a few days before the UN Water Conference that was held in March 1977 in Mar del Plata, Argentina, where shared water resources were widely and extensively debated. One of the recommendations of that Conference was that the work of the ILC on the law of the non-navigational uses of international watercourses should be given higher priority in the work program of the ILC, and be coordinated with other international bodies dealing with the development of international law of waters with a view to the early conclusion of an international convention. The Conference also recommended that, in the absence of bilateral and multilateral agreements, member states should continue to apply generally accepted principles of international law in the use, development, and management of shared water resources, and should take note of the useful work of the non-governmental and other expert bodies on international water law (United Nations, 1977b). However, as discussed below, it would take seventeen more years, following the issuance of the above recommendation, before the ILC would be able to agree on, and recommend, a draft convention to the UN General Assembly. Actually, the complexity of the issues related to shared waters surfaced even at the Mar del Plata Water Conference, and the participants in that meeting got a taste of such complexities. There was no agreement during the Conference on what term to use when referring to a watercourse, parts of which are in different states. Although the Report of the Conference used the term "shared water resources," a footnote, repeated twice, clarified that "this term has been used only for uniformity of the text and its use does not prejudice the position of the countries supporting the terms 'transboundary waters' or 'international waters' in any of the problems involved."

\section{Work of the International Law Commission}

Pursuant to Resolution 2669 of 1970 , the ILC started working on the topic of international watercourses in early 1971. The ILC is a UN body composed of legal experts nominated by states, elected by the United Nations General Assembly, and tasked with the codification and progressive development of international law. The task was clearly a complex one. It took 23 years, five rapporteurs, and fifteen reports before the final draft articles of the Convention were agreed upon by the ILC. A number of issues proved controversial and complex even for the members of the ILC. Such issues included definition of the term "international watercourses;" transboundary

\begin{tabular}{|c|c|c|}
\hline Rapporteur & Raport & Sossion and Year \\
\hline Kearney & First report & 28th session, 1976 \\
\hline Schwebel & $\begin{array}{l}\text { First report } \\
\text { Second report } \\
\text { Third report }\end{array}$ & $\begin{array}{l}\text { 31st session, } 1979 \\
\text { 32nd session, } 1980 \\
\text { 34th session, } 1982\end{array}$ \\
\hline Evensen & $\begin{array}{l}\text { First report } \\
\text { Second report }\end{array}$ & $\begin{array}{l}\text { 35th session, } 1983 \\
\text { 36th session, } 1984\end{array}$ \\
\hline McCaffrey & $\begin{array}{l}\text { First (preliminary) report } \\
\text { Second report } \\
\text { Third report } \\
\text { Fourth report } \\
\text { Fifth report } \\
\text { Sixth report } \\
\text { Seventh report }\end{array}$ & $\begin{array}{l}\text { 37th session, } 1985 \\
\text { 38th session, } 1986 \\
\text { 39th session, } 1987 \\
\text { 40th session, } 1988 \\
\text { 41st session, } 1989 \\
\text { 4.2nd session, } 1990 \\
\text { 43rd session, } 1991\end{array}$ \\
\hline \multirow[t]{2}{*}{ Rosenstock } & $\begin{array}{l}\text { First report } \\
\text { Second report }\end{array}$ & $\begin{array}{l}\text { 45th session, } 1993 \\
\text { 48th session, } 1994\end{array}$ \\
\hline & Final draft Articles & 46 th session, 1994 \\
\hline
\end{tabular}

Table 1:The Special ILC Rapporteurs and Their Reports. Source: Watts (1999). 
The United Nations Watercourses Convention Ten Years Later: Why Has its Entry into Force Proven Difficult?

groundwater; the status of existing watercourses agreements vis-a-vis the Convention; the relationship between the principle of equitable and reasonable utilization and the obligation not to cause significant harm; and the procedures and mechanisms for dispute settlement. Differences on those issues were finally resolved, and a draft Convention was agreed upon by the ILC and submitted to the General Assembly in 1994. Table 1 shows the different rapporteurs, the reports they prepared, and the ILC sessions and years during which the reports were discussed.

The draft Convention prepared by the ILC was deliberated thereafter by the Sixth Committee of the UN (the Legal Committee), convened as Working Group of the Whole (the Working Group). Thereafter, on May 21, 1997, following lengthy discussion of the ILC draft, as amended by the Working Group, the UN General Assembly passed Resolution 51/229 adopting the Convention. One hundred and three countries voted for the Convention, and three against (Burundi, China and Turkey), with 27 abstentions; while 52 countries did not participate in the voting. Subsequent to the vote, Nigeria and Fiji (which did not vote), and Belgium (which abstained), informed the Secretariat of the UN General Assembly that they had intended to vote for the Convention (United Nations General Assembly, 1997). This would have brought the number of the countries voting for the Convention to 106 , and decreased the abstentions to 26 .

The Convention was opened for signature on May 21, 1997, and remained open for three years, until May 20, 2000. By that time only 16 states had signed the Convention. Although signature closed on May 20, 2000, states can still become parties to the Convention by acceding to it. This means that they can have the Convention approved or accepted through their constitutional process without having it signed. The Convention needs 35 instruments of ratification or accession to enter into force. As of this year, ten years after its adoption, the Convention has yet to command sufficient ratifications to enter into force. It has only been ratified or acceded to by fifteen states, a number far short of that required under the Convention, as discussed later.

\section{An Overview of the Provisions of the Convention}

The Convention is based largely on the ILA work, particularly the Helsinki Rules which were issued by the ILA in 1966, and to some extent on the work of the IIL. The Convention itself recognizes "the valuable contribution of international organizations, both governmental and non-governmental, to the codification and progressive development of international law in this field." The Convention also recalled the existing bilateral and multilateral agreements regarding the nonnavigational uses of international watercourses.

The Convention is a framework convention that aims at ensuring the utilization, development, conservation, management and protection of international watercourses, and promoting optimal and sustainable utilization thereof for present and future generations. As a framework convention, it addresses some basic procedural aspects and few substantive ones, and leaves the details for the riparian states to complement in agreements that would take into account the specific characteristics of the watercourse in question. Such agreements can adopt or adjust the provisions of the Convention.

The Convention is divided into seven parts and consists of 37 articles. In addition, it includes an Annex on arbitration that consists of 14 articles. The main areas that the Convention addresses include the definition of the term "watercourse;" watercourses agreements; equitable and reasonable utilization and the obligation not to cause harm; notification for planned measures; protection, preservation and management; and dispute settlement.

Article 1 (2) of the Convention asserts that the uses of international watercourses for navigation are not within the scope of the Convention, except insofar as other uses affect navigation or are affected by navigation. It should be noted, however, that Article 10 of the Convention states that in the absence of an agreement or custom to the contrary, no use of an international watercourse enjoys inherent priority over other uses. Although it does not mention any specific uses, the Article is understood to indicate that navigational uses, which had superior status during the nineteenth and early twentieth centuries, no longer enjoy inherent priority over non-navigational uses. The 
S. M. A. Salman

Article goes further and requires that in the event of conflict between uses of an international watercourse, due regard should be given to the requirements of "vital human needs." A Statement of Understanding issued by the Working Group clarified that in determining vital human needs, "special attention is to be paid to providing sufficient water to sustain human life, including both drinking water and water required for production of food in order to prevent starvation." Article 10 has been used, together with other similar provisions in other international legal instruments, by a number of authors in the field to support the notion of a human right to water (Salman and McInerney-Lankford, 2004).

The Convention defines the term "international watercourse" to mean "a watercourse, parts of which are situated in different states." It defines the term "watercourse" to include both "surface water and groundwaters constituting by virtue of their physical relationship a unitary whole and normally flowing into a common terminus." This definition includes only groundwater that is connected to surface water. It does not include transboundary aquifers that do not contribute water to, or receive water from, surface waters. Realizing this lacuna, the ILC issued a separate resolution recommending that other types of groundwater be governed by the same rules laid down in the Convention (Salman, 1999).

Watercourse agreements are dealt with in Article 3 of the Convention. The Article indicates that the Convention shall not affect the rights or obligations of a watercourse state arising from agreements that are in force. However, the Article asks the parties to consider, where necessary, harmonizing such agreements with the basic principles of the Convention. Article 3 also allows watercourse states to enter into agreements which apply and adjust the provisions of the Convention to the characteristics and uses of a particular international watercourse. Furthermore, the Article states that when some, but not all, watercourse states to a particular international watercourse are parties to an agreement, nothing in such an agreement would affect the rights or obligations under the Convention of watercourse states that are not parties to such an agreement.

The Convention embraces the principle of equitable and reasonable utilization, and lays down in Article 6 certain factors and circumstances that should be taken into account for determining such equitable and reasonable utilization. Article 6 (1) of the Convention states that utilization of an international watercourse in an equitable and reasonable manner within the meaning of Article 5 requires taking into account all relevant factors and circumstances, including: (a) geographic, hydrographic, hydrological, climatic, ecological and other factors of a natural character; (b) the social and economic needs of the watercourse states concerned; (c) the population dependent on the watercourse in the watercourse state; (d) the effects of the use or uses of the watercourse in one watercourse state on other watercourse states; (e) existing and potential uses of the watercourse; ( $f$ ) conservation, protection, development and economy of the water resources of the watercourse and the cost of measures taken to that effect; and $(\mathrm{g})$ the availability of alternatives, of comparable value, to a particular planned or existing use. In this connection, the Convention follows the same approach adopted thirty years earlier by the Helsinki Rules, which established the principle of equitable and reasonable utilization as the guiding principle for international water law, and laid down certain factors for determining such equitable utilization. In comparing the above factors with the factors under the Helsinki Rules, it can be concluded that the factors under the UN Convention are based largely on those of the Helsinki Rules. In line with Article $\mathrm{V}$ of the Helsinki Rules, Article 6 of the Convention states that the weight to be given to each factor is to be determined by its importance in comparison with that of other relevant factors. Similarly, the Article clarifies that in determining what is reasonable and equitable use, all relevant factors are to be considered together and a conclusion reached on the basis of the whole.

The Convention also deals in Article 7 with the obligation not to cause significant harm, and requires the watercourse states to take all appropriate measures to prevent the causing of significant harm to other watercourse states. Agreement on which rule takes priority proved quite difficult, and the issue occupied the ILC throughout its work on the Convention. Each rapporteur dealt with the issue differently, equating the two principles, or subordinating one principle to the other. The issue was discussed in the Working Group where sharp differences between the riparian states on those two principles surfaced. It is worth clarifying in 
The United Nations Watercourses Convention Ten Years Later: Why Has its Entry into Force Proven Difficult?

this connection that lower riparians tend to favor the no harm rule, as it protects existing uses against impacts resulting from activities undertaken by upstream states. Conversely, upper riparians tend to favor the principle of equitable and reasonable utilization, because it provides more scope for states to utilize their share of the watercourse for activities that may impact on downstream states. After a lengthy debate by the Working Group, a compromise regarding the relationship between the two principles was reached. The compromise addressed Articles 5 and 6 (equitable and reasonable utilization) and Article 7 (obligation not to cause significant harm). The new language of Article 7 requires the state that causes significant harm to take measures to eliminate or mitigate such harm "having due regard to articles 5 and 6." Those two Articles deal with the principles of equitable and reasonable utilization. As Lucius Caflisch noted "The new formula was considered by a number of lower riparians to be sufficiently neutral not to suggest a subordination of the no-harm rule to the principle of equitable and reasonable utilization. A number of upper riparians thought just the contrary, namely that, that formula was strong enough to support the idea of such subordination." (Caflisch, 1998). Although the compromise facilitated adoption of the Convention by the UN General Assembly, second thoughts about this compromise started surfacing in the minds of many states, as will be discussed later.

However, notwithstanding this compromise language, the prevailing view is that the Convention has subordinated the obligation not to cause significant harm to the principle of equitable and reasonable utilization. This conclusion is based on a close reading of Articles 5,6 and 7 of the Convention. Article 6 enumerates a number of factors for determining equitable and reasonable utilization. Those factors include (i) "the effects of the use or uses of the watercourse in one watercourse State on other watercourse States," and (ii) "existing and potential uses of the watercourse." Those same factors will also need to be used, with other factors, to determine whether significant harm is caused to another riparian, because harm can be caused by depriving other riparians of the water flow and thereby affecting their existing uses. Moreover, Article 7 (1) of the Convention obliges watercourse states, when utilizing an international watercourse in their territory, to take all appropriate measures to prevent the causing of significant harm to other watercourse states. When significant harm nevertheless is caused to another watercourse state, then Article 7 (2) of the Convention requires the state causing the harm to "take all appropriate measures, having due regard to Articles 5 and 6 , in consultation with the affected State, to eliminate or mitigate such harm, and where appropriate, to discuss the question of compensation." As noted before, Articles 5 and 6 of the Convention deal with equitable and reasonable utilization. As such, Article 7 (2) requires giving due regard to the principle of equitable and reasonable utilization when significant harm has nevertheless been caused to another watercourse state. The paragraph also indicates that the causing of harm may be tolerated in certain cases such as when the possibility of compensation may be considered. Accordingly, a careful reading of Articles 5, 6 and 7 of the Convention should lead to the conclusion that the obligation not to cause harm has indeed been subordinated to the principle of equitable and reasonable utilization. Hence, it can be concluded that, similar to the Helsinki Rules, the principle of equitable and reasonable utilization is the fundamental and guiding principle of the UN Watercourses Convention.

This view has been endorsed by the International Court of Justice in the Danube case between Hungary and Slovakia (the Gabcikovo-Nagymaros case). The case was decided in September 1997, four months after the Convention was adopted by the UN General Assembly. In that case the Court emphasized the concept of equitable and reasonable utilization when it directed that "the multi-purpose programme, in the form of a co-ordinated single unit, for the use, development and protection of the watercourse is implemented in an equitable and reasonable manner." (ICJ, 1997, paragraph 150). The Court did not refer to the obligation not to cause harm.

Other basic obligations under the Convention include the obligation to cooperate through, inter alia, the establishment of joint mechanisms or commissions, and the regular exchange of data and information, and through notification of other riparian states of planned measures with possible significant adverse effects. Planned measures are dealt with in Part III of the Convention. This is the longest part of the Convention 
S. M. A. Salman

and includes nine articles that address a number of aspects related to notification of other riparians of planned measures that may cause significant adverse effects. Those aspects include the period for reply; obligations of the notifying state during the period for reply; reply for notification, and absence of reply; consultations and negotiations concerning planned measures; procedures in the absence of notification; and urgent implementation of planned measures.

Environmental protection of international watercourses is dealt with under Part IV, Articles 20 to 26 of the Convention, entitled "Protection, Preservation and Management" of international watercourses. This part establishes a number of obligations on the watercourse states, including protection and preservation of ecosystems; prevention, reduction and control of pollution; introduction of alien or new species; and protection and preservation of the marine environment. A Statement of Understanding issued by the Working Group clarified that those Articles impose a due diligence standard on watercourse states.

Article 33 and the Annex to the Convention deal with dispute settlement mechanisms and procedures. The Article lays down a number of methods for settlement of disputes, including negotiations, jointly seeking the good offices of, or mediation and conciliation by a third party, or use of joint watercourse institutions, or submission of the dispute to arbitration or to the International Court of Justice. However, the method for settlement of a particular dispute should be agreed upon by both parties. The only obligatory method set forth in the Convention is impartial fact finding. Although Article 33 lays down detailed procedures for such fact finding, it only requires the partics to consider the report of the fact finding commission in good faith. Similarly, the Convention provides the parties with the option to submit their dispute for arbitration in accordance with detailed rules laid down in the Annex to the Convention, or to the International Court of Justice. Again this is not obligatory, but merely an option.

This overview indicates that the Convention is basically a framework convention which lays down basic principles and procedures, leaving the details to the watercourse states to complement in agreements that take into account the characteristics of their specific watercourse.

\begin{tabular}{|c|c|c|}
\hline Country & Region & Dete of Bocoming Party \\
\hline South Africa & Africa & 26 October 1998 \\
\hline Namibia & Africa & 29 August 2001 \\
\hline Finland & Europe & 23 January 1998 \\
\hline Nonway & Europe & 30 September 1998 \\
\hline Hungary & Europe & 26 January 2000 \\
\hline Sweden & Europe & 15 June 2000 \\
\hline Netherlands & Europe & 9 January 2001 \\
\hline Portugal & Europe & 22 June 2005 \\
\hline Germany & Europe & 15 January 2007 \\
\hline Syria & Middle East & 2 April 1998 \\
\hline Lebanon & Middle East & 25 May 1999 \\
\hline Jordan & Middle East & 22 June 1999 \\
\hline Iraq & Middle East & 9 July 2001 \\
\hline Qatar & Middle East & 28 February 2002 \\
\hline Libya & Middle East & 14 June 2005 \\
\hline
\end{tabular}

Table 2:Parties to the UN Watercourses Convention Source: United Nations Treaty Series (2007).

\section{Status of the Convention}

Almost ten years after its adoption by a majority exceeding one hundred states, the Convention has not yet obtained the necessary number of instruments of ratification or accession to enable it to enter into force and effect. As shown in Table 2 below, only fifteen states are thus far parties to the Convention.

As indicated in Table 2 above, most of the ratifications took place in the first three years (1998 to 2001 ), with only four ratifications thercafter. Seven of the fifteen states that have ratified or acceded to the Convention are in Europe, six in the Middle East, and two in Africa. No country from Asia or the Amcricas is a party to the Convention yet. Finland, expressing commitment to, and faith in the Helsinki Rules, was the first country to ratify the Convention. It did so in January 1998, eight months after the adoption of the Convention by the General Assembly, and about three months after it signed the Convention on October 31 , 1997. However, it should be clarified that Syria was the first country to sign the Convention, which it did on August 11, 1997, but it ratified it in April 1998, three months after Finland. Germany signed the Convention in 1998, but ratified it close to nine years later in 2007.

It is worth noting that two of the countries that signed and ratified the Convention, namely Lebanon and Iraq, did not participate in the voting at the UN General Assembly meeting in May 1997. In contrast, none of the three countries that informed the Secretariat of the UN General Assembly that they had intended to vote for the 
The United Nations Watercourses Convention Ten Years Later: Why Has its Entry into Force Proven Difficult?

\begin{tabular}{|c|c|c|}
\hline Country & Region & Date of Signature \\
\hline Cotê d'Ivoire & Africa & 25 September 1998 \\
\hline Yemen & Middle East & 17 May 2000 \\
\hline Tunisia & Middle East & 19 May 2000 \\
\hline Luxembourg & Europe & 14 October 1997 \\
\hline Venezuela & South America & 22 September 1997 \\
\hline Paraguay & South America & 25 August 1998 \\
\hline
\end{tabular}

Table 3: States that Signed but not yet Ratified the UN Watercourses Convention. Source: United Nations Treaty Series (2007).

Convention (Belgium, Fiji, and Nigeria) is a party to the Convention. Interestingly, two of the countries that are parties to the Convention, Qatar and Libya, have no surface water to share with other countries, and the groundwater they share with other countries may not even be covered by the Convention. This is because such groundwater has no physical relationship to any surface water, and as such is outside the definition of the term "watercourse" under the Convention.

Six of the states that signed the Convention before it closed for signature on May 20, 2000, have not yet ratified the Convention, as shown in Table 3 below. In addition to Africa, Europe and the Middle East, the list of the signatory countries includes two South American countries. One of those two countries, Paraguay, actually abstained during the voting for the Convention at the UN General Assembly. Venezuela was one of the first countries to sign the Convention. It did so in September 1997, four months after the Convention was adopted, but is not yet a party. So is Luxembourg which signed the Convention in 1997. Tunisia was the last country to sign the Convention, doing so on May 19, 2000, one day before the Convention closed for signature. It is noteworthy that the list in this Table, like that under Table 2, includes no country from Asia.

Clearly, there is a great deal of reluctance to be a party to the Convention from most of the states - the ones that voted for the Convention in 1997, some of those that abstained or did not attend the session, and those that indicated after the session that they had intended to vote for the Convention.

\section{Why Are States Reluctant to become Parties to the Convention?}

An immediate question that arises is: why have the more than one hundred states that voted for the Convention in May 1997 been reluctant to sign and ratify, or accede to, the Convention? A review of the various statements made by the different delegations during the discussion of the Convention by the Working Group and the UN General Assembly (United Nations General Assembly, 1997), and presentations made by, and discussion with various government officials from different countries, reveals a number of different, and sometimes inaccurate perceptions and interpretations of the provisions of the Convention. Those interpretations and misconceptions have no doubt contributed to the slow pace of the signing, ratification of, and accession to the Convention. Suffice it here to briefly review and comment on six such areas.

The first and most important area of contention is the relationship between the principle of equitable and reasonable utilization and the obligation not to cause harm. The compromise language regarding the relationship between the two reached by the Working Group and discussed above, facilitated the process of approval of the Convention by the General Assembly. Nonetheless, upper riparians still seem to consider the Convention as biased in favor of lower riparians because of its specific and separate mention of the obligation not to cause harm. This specific and separate reference of the obligation not to cause harm is viewed as equating it with the principle of equitable and reasonable utilization. It is to be noted that the three countries that voted against the Convention (Burundi, China and Turkey), and some of those that abstained, such as Bolivia, Ethiopia, Mali and Tanzania, are largely upper riparian states. On the other 
S. M. A. Salman

hand, a number of downstream states, such as Egypt, France, Pakistan and Peru, also abstained, concerned that the Convention favors upstream riparians because it subordinates the no harm rule to the concept of equitable and reasonable utilization. This is basically the position that most states took at the Working Group before the compromise language of Article 7, discussed above, was accepted. Clearly, most of the states that accepted that compromise at that time are no longer convinced that the compromise really serves their interests.

However, as Table 2 shows, those two positions do not reflect the unified position of either upstream riparians or the downstream ones. A number of the countries that ratified the Convention, such as Iraq, the Netherlands, Portugal and South Africa are lower riparians. Hence, the perception by the upstream riparians that the Convention is biased in favor of downstream riparians, and vice versa, is, no doubt, one of the main reasons for the stalling of the process of the signature and ratification of, or accession to the Convention.

As indicated before, lower riparians tend to favor the no harm rule, as it protects existing uses against impacts resulting from activities undertaken by upper riparians. Conversely, upper riparians tend to favor the equitable and reasonable utilization principle because it provides more scope for states to utilize their share of the watercourse for activities that may impact on downstream states. It is true that the Convention has subordinated the no harm rule to the principle of equitable and reasonable utilization. Yet, this should in no way be viewed as favoring upstream riparians. The principle of equitable and reasonable utilization, which has been the guiding principle of international law since the Helsinki Rules were issued in 1966, duly recognizes, and is based on, the equality of all the riparians in the uses of the shared watercourse. It further lays down certain objective factors for determining the equitable and reasonable share for each riparian state, and those factors include existing uses.

Related to the view that the Convention is biased in favor of downstream riparians is the perception by upper riparians that the notification process under the Convention favors downstream riparians and provides them with a veto power over projects and programs of upstream riparians. Unfortunately, it is widely believed that notification is an exclusive right of lower riparians because only upstream riparians can cause harm to downstream riparians by affecting the quantity and quality of water flows to such downstream riparians. This belief is actually incorrect and is one of the basic misconceptions about international water law in general, and the Convention in particular. It is a common mistaken belief among a large segment of lawyers and non-lawyers that harm can only "travel" downstream, and it is not recognized that upstream states can also be harmed by activities by downstream states. In other words, this mistaken notion is based on the assumption that only upstream riparians can harm downstream riparians. It is obvious, and clearer, that the downstream riparians can be harmed by the physical impacts of water quality and quantity changes caused by use by upstream riparians. It is much less obvious, and generally not recognized, that the upstream riparians can be harmed by the potential foreclosure of their future use of water caused by the prior use and the claiming of rights by downstream riparians. For example, a poor upstream country could be precluded from developing the water resources of an international waterway tomorrow if a richer downstream riparian, without consultation or notification, develops it today. This is an important, albeit not widely understood, principle of international water law which establishes a clear linkage between the principle of equitable and reasonable utilization, and the obligation not to cause harm. It should be noted, nonetheless, that there is a gradual but growing realization by some countries of the linkage between the two principles, which is a first step in understanding the concept of "potential foreclosure of future uses." For example, Ethiopia, the upper most riparian of the Blue Nile Basin, protested to Egypt and Sudan when the two countries concluded the 1959 Nile Agreement that divided the Nile waters exclusively between them. Ethiopia has since been protesting most of the projects undertaken by Egypt and Sudan on the Nile because it has realized that those projects potentially foreclose its future uses of the Nile waters and deprives it of its equitable and reasonable share of the Nile waters. Moreover, an understanding of this concept has been reflected in some recent treaties. The Senegal River Water Charter which was concluded by Senegal, Mauritania and Mali in May 2002, and 
which Guinea signed in 2006, enumerates in Article 4 a number of principles for allocation of the waters of the Senegal River. Such principles include "the obligation of each riparian state to inform other riparian states before engaging in any activity or project likely to have an impact on water availability, and/or the possibility to implement future projects."

For this reason, the World Bank Policy for Projects on International Waterways (Operational Policy 7.50), and the way it has been interpreted and applied, requires notification of all riparians, both downstream as well as upstream, underscoring the fact that harm is actually a two way matter (World Bank, 2001). Indeed, one of the few objections to a Bank-financed project came from an upstream riparian. The Bank had planned financing the Baardhere Dam Project on the Juba River in Somalia in the late 1980s. The Juba River originates in Ethiopia, and the Ethiopia-Kenya borders, and flows through Somalia before emptying into the Indian Ocean. Both Ethiopia and Kenya were notified of the Project by the World Bank on behalf of Somalia. Ethiopia objected claiming that the Project did not take into consideration its present and future hydropower and irrigation development. Ethiopia further demanded that the two countries should first enter into negotiations for determining the amount of water from the Juba River that each country would need. Consequently, the Bank decided to obtain an opinion from independent experts, as set forth in Operational Policy 7.50. The experts noted that Ethiopia, Somalia and Kenya have a right to an equitable and reasonable share in the utilization of the Juba basin waters, but went on to conclude that the Project would not cause any appreciable harm to the present legitimate rights or interests of Ethiopia and Kenya. Basically, the experts determined that the amount of water that Somalia would use under the Project falls within its equitable and reasonable share, and as such there would be no harm to Ethiopia. This determination confirms the close linkage between the principle of equitable and reasonable utilization and the obligation not to cause harm. It further clarifies how harm can be a two-way matter.

Similarly, the Convention, and before it the Helsinki Rues, do not limit notification to downstream riparians, nor grant any state such a veto power over the projects and programs of other riparian states. The
Convention requires notification in case a project may cause "significant adverse effects" to other riparians, and lays down detailed provisions, including failure to notify. Furthermore, it sets forth procedures in case of an objection by one or more of the riparian states. In such a case, the Convention requires the parties to enter into consultations and, if neccssary, negotiations with a view to arriving at an equitable resolution of the situation. The Convention further requires that each state must in good faith pay reasonable regard to the rights and legitimate interests of the other state.

Accordingly, the Convention, reflecting customary international water law, requires notification of both downstrcam as well as upstream riparians, only in case a project is expected to cause significant adverse effects on any other riparian, downstream or upstream, and lays down certain procedures in case of an objection. It does not require notification if the project is not expected to cause significant adverse effects, nor does it grant a veto power to any riparian over planned measures of another riparian.

A third issue that has contributed to the reluctance of some states to become parties to the Convention is the manner in which the Convention has dealt with existing agreements. As indicated earlier, the Convention does not affect the rights or obligations of watercourse states arising from agreements that are in force. Nonetheless, it asks the parties to consider, where necessary, harmonizing such agreements with the basic principles of the Convention. It also allows watercourse states to enter into agreements which apply and adjust the provisions of the Convention to the characteristics and uses of a particular international watercourse. Furthermore, the Convention states that when some, but not all, watercourse states to a particular international watercourse are parties to an agreement, nothing in such an agreement would affect the rights or obligations under the Convention of watercourse states that are not parties to such an agreement.

Riparian states that already have agreements in place believe that the Convention has not fully recognized those agreements because it suggests that the parties may consider harmonizing such agreements with the principles of the Convention. Conversely, riparian states that have been left out of existing agreements believe that the Convention should have subjected those agreements 
S. M. A. Salman

to the provisions of the Convention, and should have required consistency between the two. However, a close reading of the provisions of the Convention reveals that the Convention recognizes both, the validity of existing agreements, as well as the right of the riparian states which are not parties to such agreements in the shared watercourse. The Convention could not have simply annulled those existing agreements, because such a provision would have been rejected by most members of the General Assembly, and would have resulted in chaos in a number of basins. Any number of riparian states has the right under international law to enter into an agreement regarding the shared watercourse, but that right is also subject to the rights of other riparians in the uses of the shared watercourse. The Convention has basically reflected this legal and common sense principle. It should be recalled that the Convention is a framework convention that lays down basic principles that are to be complemented by agreements between the parties, taking into account the characteristics of the specific watercourse.

A fourth area of contention is the belief by some riparian states that the dispute settlement provisions of the Convention are too weak because they do not provide for any binding mechanism. In contrast, other riparian states view the fact finding procedures of the Convention as a compulsory method, and argue that such a fact finding method interferes with their sovereign right of choosing the dispute settlement procedures. As discussed earlier, the Convention suggests for the parties a number of methods for settlement of disputes, including negotiations, jointly seeking the good offices of, or mediation and conciliation by a third party, or use of joint watercourse institutions, or submission of the dispute to arbitration or to the International Court of Justice. The only obligatory method set forth in the Convention is impartial fact finding where the parties are required to consider the report of the fact finding commission in good faith.

Thus, the Convention provides a basic mechanism for ascertaining the facts of the dispute, and leaves it for the parties to agree on the method for resolving it from a wide menu of choice. This is quite reasonable given that the Convention is a framework one. Yet again, neither side seems to be satisfied with this compromise.
A fifth area of misunderstanding by some states concerns the expanded definition under the Convention of the term "Watercourse State" to include "regional economic integration organizations." The Convention defines "Watercourse State" to mean "a State Party to the present Convention in whose territory part of an international watercourse is situated, or a Party that is a regional economic integration organization, in the territory of one or more of whose Member States part of an international watercourse is situated." Furthermore, it defines regional economic integration organization as "an organization constituted by sovereign States of a given region, to which its member States have transferred competence in respect of matters governed by this Convention and which has been duly authorized in accordance with its internal procedures to sign, ratify, accept, approve or accede to it." The Convention allows each such organization to sign and ratify the Convention, thus becoming a party to the Convention. A Statement of Understanding issued by the Working Group clarified that nothing in the paragraph defining the term "Watercourse State" "could be taken to imply that regional economic integration organizations have the status of states in international law."

A number of states have misunderstood those provisions of the Convention as allowing members of one such organization, which are not riparians to a certain watercourse, to become riparians simply because the organization has become a member. It is true that the language of the above quoted paragraphs may be difficult to follow, but there is nothing in the language of those paragraphs that would allow such an interpretation. The organization is simply acting in its capacity as a juridical entity, endowed with legal personality independent of the member states. It is taking decisions on behalf of that state because that state has transferred competence in respect of matters governed by the Convention to this organization. The mere fact that the organization has become a party to the Convention would in no way mean that the other members of the organization would become riparians to the watercourse in question. Actually, the term regional economic integration organization was added to the Convention by the Working Group to allow participation, in particular, of the European Union (McCaffrey, 2001). 
12

The United Nations Watercourses Convention Ten Years Later: Why Has its Entry into Force Proven Difficult?

As discussed carlier, the compromising manner in which the Convention has dealt with some of the issues discussed above provided the basis for its wide acceptability, and facilitated its adoption by the General Assembly in 1997. Nonetheless, it appeared that most of the more than one hundred states that voted for the Convention have had second thoughts about signature (and/or ratification), and now have the same thoughts about accession to the Convention. Those second thoughts are no doubt prompted by the above mentioned inaccurate interpretations of the Convention.

Another reason for the reluctance of some states to become parties to the Convention is the apprehension about loss of sovereignty over shared waters. Actually, during the General Assembly discussion of the draft Convention, a few states criticized the Convention for its failure to refer to the sovereignty of the watercourse states over the parts of the international watercourses located in their territory (United Nations General Assembly, 1997). This notion indicates a total failure to comprehend the basic rules of contemporary international water law that have long rejected the principle of absolute territorial sovereignty. It is now generally agreed that the "management of international watercourses should be determined less by the traditional notion of 'restricted sovereignty' than by a positive spirit of cooperation and effective interdependence." (Green Cross, 2000).

It should be clarified that there is no terminal date by which the Convention must enter into force and effect. It will do so whenever it attains the required number of 35 instruments of ratification and accession, regardless of how long it may take. It is not unusual for complex and controversial conventions to take a considerably long time to enter into force. The Law of the Sea Convention took almost twelve years to do so. However, judging from the extremely slow process of signature, ratification and accession due to the misconceptions discussed above, the risk persists that the Convention may actually not enter into force because it does not seem that it will attain the required number of ratification and accession instruments.

\section{Role and Prospects of the Convention}

Even if the Convention does not receive the necessary number of instruments of ratification and accession that would enable it to enter into force and effect, the Convention has already shown considerable influence on multilateral and bilateral water treaties. It has also been endorsed by a number of international entities as well as by the International Court of Justice. The fourteen Southern African Development Community (SADC) member countries revised their 1995 Protocol on Shared Watercourse Systems in 2000 to make it consistent with the provisions of the Convention. Indeed, most of the articles of the Revised Protocol on Shared Watercourses in the Southern African Development Community are a copy of the articles of the Convention (Salman, 2001). The Protocol refers in its Preamble to "the progress with the development and codification of international water law initiated by the Helsinki Rules and followed by the adoption by the United Nations of the UN Watercourses Convention." More specifically, the Protocol adopts the same definition for the term "watercourse", and lays down the same factors for equitable and reasonable utilization, and the same procedures for notification. Furthermore, the environmental provisions and those related to management, regulation and installations are largely a reiteration of those of the Convention. The Protocol for Sustainable Development of Lake Victoria Basin (2003), and the Agreement on the Establishment of the Zambezi Watercourse Commission (2004), both include the same factors for determining equitable and reasonable utilization, as well as provisions for notification regarding planned measures, similar to those of the Convention.

The influence and relevance of the Watercourses Convention has also been underscored by the International Court of Justice in the Danube case referred to above. In addition to endorsing the principle of cquitable and reasonable utilization, the Court confirmed the perfect equality of all riparian States in the uses of the whole course of the river, and the exclusion of any preferential privilege of one riparian state in relation to the others. The Court further noted that modern development of international law has strengthened this principle for non-navigational uses of international watercourses "as evidenced by the adoption of the Convention of 21 May 1997 on the Law of the Non-Navigational Uses of International Watercourses by the United Nations 
S. M. A. Salman

General Assembly." (ICJ, 1997, paragraph 85).

It should be added that the Convention was endorsed by a number of international entities. The World Commission on Dams indicated that "the principles embodied in the 1997 UN Convention on the Law of the Non-Navigational Uses of International Watercourses warrant support. States should make every effort to ratify the Convention and bring it into force." (World Commission on Dams, 2000). The World Water Council described the provisions of the Convention as sensible and concluded that "Sadly enough, even after all that time [it took to prepare the Convention], it now seems unlikely that this Convention will be ratified by enough countries to enter into force." (Cosgrove and Rijsberman, 2000). Although the World Commission for Water in the $21^{\text {st }}$ Century referred to the UN Convention as "weak", the Commission added "Surely, weak as it is, it [the Convention] deserves to be approved if only as a first step towards a greater appreciation of the international character of water." (World Commission for Water in the $21^{\text {st }}$ Century, 2000). The ILA, in its Helsinki Conference held in August 1996, adopted a resolution on the then draft UN Watercourses Convention. The resolution took note "with satisfaction of the completion of the work of the United Nations International Law Commission on the topic of the nonnavigational uses of international watercourses." (ILA, 1996). It also took note with satisfaction of the General Assembly resolution convening the Sixth Committee as a Working Group of the Whole to elaborate a convention on the basis of the ILC draft.

Moreover, a number of experts consider the basic principles laid out in the Convention such as the principle of equitable and reasonable utilization, the obligation not to cause harm, notification and exchange of data and information, and the provisions regarding protection of the environment, as reflecting the basic principles of customary international water law (McCaffrey, 1998). Thus, even if the Convention does not enter into force, it has received broad endorsements, and it is widely agreed that it reflects and embodies the basic principles of international water law.

\section{Conclusion}

The adoption of the UN Watercourses Convention by the General Assembly on May 21, 1997 marked an historic moment in the evolution of international water law. The approval of the Convention came at a time when water resources management, whether at the national or international level, started facing major challenges, resulting largely from the unprecedented population growth, environmental degradation, urbanization and industrialization. Those challenges led to the sharpening of the competing demands of riparian states, and to an increasing attention to water resources world-wide. The establishment of the Global Water Partnership and the World Water Council in 1996, and the convening by the World Water Council of the four World Water Forums between 1997 and 2006 (in Marrakech, TheHague, Kyoto and Mexico City, respectively), are clear indications of this global attention. Those forums underscored, among other things, the fact that international water can be a catalyst for cooperation as well as a cause for conflict, and emphasized the pressing need for collaborative action that the Convention epitomizes. In addition, the Convention has received the endorsements of World Water Council, the World Commission on Water for the $21^{\text {st }}$ Century, the World Commission on Dams, and more importantly, the International Court of Justice.

However, despite this wide recognition of the challenges facing water resources, and the broad acceptance and endorsement of the UN Watercourses Convention, the Convention has not yet commanded even half the number of ratification or accession instruments needed to enable it to enter into force. This situation is due largely to the reluctance of the states to be parties to the Convention. Of the more than one hundred countries that voted for the Convention, only thirteen have become parties. The two other parties to the Convention did not participate in the voting, but have signed and ratified the Convention. One country that abstained during the voting, signed but has not yet ratified the Convention. The three countries that indicated their approval of the Convention after the General Assembly vote took place are still to become parties, and one country took eight years to ratify the Convention. Of the fourteen African countries that ratified or acceded to the SADC Protocol, only two are parties to the Convention, notwithstanding the fact that the principles of the Protocol are largely a reiteration of those of the Convention. This reluctance of states 
The United Nations Watercourses Convention Ten Years Later: Why Has its Entry into Force Proven Difficult?

to become parties to the Convention emanates, as published work includes "Regulatory Frameworks for discussed earlier, from concerns that their interests may Water Resources Management - A Comparative Study not be well served by the Convention. Unfortunately, as the previous part of this article shows, those concerns are based largely on inaccurate interpretations of, and misconceptions about the Convention.

Water is the most important resource that human kind shares. It is a finite resource, with no alternative, and upon which there is total dependence. Close to 300 rivers, 100 lakes, and a yet to be determined number of aquifers are shared by two or more states. About $40 \%$ of the world population, in more than 140 countries, live or depend on those shared watercourses. Yet, shared watercourses continue to remain without a universal treaty in force regulating their use and protection. The UN Watercourses Convention is a framework convention which addresses basic substantive and procedural matters, and leaves the details to the watercourse states themselves to negotiate and agree upon. The provisions of the Convention on those basic matters reflect a compromising language that takes into account the interests and concerns of all riparian states. The Convention calls for cooperation on the basis of sovereign equality, territorial integrity, and mutual benefit in order to attain optimal utilization of the international watercourse for the present and future generations, thus laying the general framework for mutually beneficial utilization by all the riparians. No doubt, the Convention is and will continue to be the most authoritative instrument in the field of International Water Law. It is indeed quite unfortunate that after close to 27 years of preparatory work, and 10 years after its adoption, the UN Watercourse Convention stands little chance of entry into force. Clearly, concerted efforts are urgently needed to address the inaccurate interpretations and perceptions about some of its basic provisions.

\section{About the Author:}

Dr. Salman M. A. Salman is lead counsel with the Legal Vice Presidency of the World Bank in Washington DC and is the Bank adviser on water law. Dr. Salman has published extensively in the area of national and international water law. His most recent (with Daniel Bradlow; Law, Justice, and Development Series, The World Bank, 2006); and Chapter 15 of the Oxford Handbook on International Environmental Law on "Ocean and Freshwater Resources" (with David Freestone; Oxford University Press, 2007). Dr. Salman is also the editor of the "Law, Justice, and Development Series" of the Legal Vice Presidency of the World Bank.

\section{Acknowledgements and Disclaimer:}

The author would like to thank Charles Di Leva, Fuad Bateh and Shehan de Sayrah for helpful comments on an earlier draft of this article. The views expressed in this article are those of the author and do not necessarily reflect the views of the World Bank or any of the institutions with which the author is affiliated. Information about the states that have signed, ratified or acceded to the Convention is current as of end of January, 2007.

\section{References:}

Berber, F. J. 1959. Rivers in International Law. London: Stevens \& Sons Limited.

Bourne, C. 1996. "The International Law Association's contribution to International Water Resources Law." Natural Resources Journal, 36: 155-216.

Caflisch, L. 1998. "Regulation of the uses of international watercourses." In S. Salman \& L. Boisson de Chazournes (Eds.), International Watercourses - Enhancing Cooperation and Managing Conflict. Washington, DC: World Bank Technical Paper No. 414, pp. 3-16.

Cosgrove, W. and F. Rijsberman, 2000. World Water Vision - Making Water Everybody's Business. London, UK: World Water Council.

Green Cross, 2000. National Sovereignty and International Watercourses (Geneva), p.18. Geneva, Switzerland: Green Cross International.

ICJ (1997). International Court of Justice, GabcikovoNagymaros Case (Hungary v. Slovakia), General List No. 92, 25 September 1997.

ILA (1966). International Law Association, Report of the Fifty-Second Conference, Helsinki (London

IWRA, Water International, Volume 32, Number 1, March 2007 
S. M. A. Salman

1967), pp. 447-533.

ILA (1996). International Law Association, Report of the Sixty-Seven Conference, Helsinki (London, 1996), p. 416.

McCaffrey, S. 2001. The Law of International Watercourses - Non-Navigational Uses. New York, NY: Oxford University Press.

McCaffrey, S. 1998. "The UN Convention on the law of the non-navigational uses of international watercourses: prospects and pitfalls." In International Watercourses - Enhancing Cooperation and Managing Conflict (S. Salman \& L. Boisson de Chazournes, Eds.). Washington, DC: World Bank Technical Paper No. 414, pp. 17-28.

Salman S. 1999. Groundwater - Legal and Policy Perspectives. Washington, DC: World Bank Technical Paper No. 456.

Salman, S. 2001. "Legal regime for use and protection of international watercourses in the Southern African region: evolution and context." Natural Resources Journal 41(4): 981-1022.

Salman S. and S. McInerney-Lankford. 2004. The Human Right to Water - Legal and Policy Dimensions. Washington, DC: Law, Justice, and Development Series, The World Bank.

United Nations. 1963. Legal Problems Relating to the Utilization and Use of International Rivers, Report of the Secretary-General, A/5409, 15 April 1963.

United Nations. 1977a. Register of International River Basins, Report of the Secretary General, E/ C.7/71, 11 March 1977.

United Nations. 1977b. Report of the United Nations Water Conference, Mar del Plata, 14-15 March 1977, Sales No. E.77.11.A.12.

United Nations General Assembly. 1997. General Assembly Adopts Convention on Law of Non-Navigational Uses of International Watercourses, Press Release GA/9248, May 21, 1997.

United Nations Treaty Series. 2007. Convention on the Law of the Non-Navigational Uses of International Watercourses. [Online] URL: http://untreaty.un.org/ENGLISH/bible/ englishinternetbible/partI/chapterXXVII/ treaty42.asp

Watts, A. 1999. The International Law Commission (1949-1998), Volume Two: The Treaties, Part II. Oxford, UK: Oxford University Press.

World Bank. 2001. Operational Policy and Bank Procedures 7.50, Projects on International Waterways. [online] URL: http://web. worldbank.org/WBSITE/EXTERNAL/ PROJECTS/EXTPOLICIES/EXTSAFEPOL 0,,contentMDK:20544007 menuPK:1286706 pagePK:64168445 piPK:64168309 theSitePK :584435,00.html.

World Commission for Water in the $21^{\text {st }}$ Century. 2000. A Water Secure World - Vision for Water, Life and the Environment. London, UK: World Commission on Water, London.

World Commission on Dams. 2000. Dams and Development - A New Framework for Decisionmaking (The Report of the World Commission on Dams). London, UK: Earthscan Publications.

IWRA, Water International, Volume 32, Number 1, March 2007 